UDC 332.1

JEL Classification: Q001

Fedulova S.O., Bilobrova O.V.

\title{
ASSESSMENT OF SUSTAINABLE DEVELOPMENT OF THE REGION ON THE BASIS OF NATURAL RESOURCE SPECIALIZATION
}

\author{
Ukrainian State University of Chemical Technology, Dnipro, Ukraine
}

\begin{abstract}
The existing approaches to assessing the level of sustainable development of the region has been analyzed in the article. It is noted that this issue has wide coverage, but the existing regional asymmetries of Ukrainian territories require further improvement of existing knowledge. From the standpoint of the system approach, the region is a complex socioeconomic system, since it consists of a multitude of interconnected elements (subsystems, components) that act as a certain integrity. The most important methodological task is the definition of factors that ensure the movement of the regional socio-economic system along the trajectory of sustainable development, as well as the justification of criteria and a system of indicators that allow assessing the degree of its sustainability. The vast majority of methods for assessing the sustainable development of regions at the levels of consideration of both individual countries and certain units within countries is based on the use of comparisons and ranking of regions by rating values. The subject of the study is practically all areas related to human activity. In accordance with the objectives of regional development, a system of criteria (characteristics of development) and indicators that measure their effectiveness are being developed. Despite the existing differences between countries and regions in the hierarchy of values and for development, international organizations assess the degree of development of countries and regions by some universal integrated, aggregating indicators. Development of theoretic - methodological measuring device of steady development, that will allow simply to interpret the got result presents high both research value and administrative. It is necessary to take into account the natural - resource specialization of the region in the development of theoretical bases of assessment of sustainable development of the region.
\end{abstract}

Keywords: region; sustainable development; index; rating; natural - resource specialization of the region; territorial development; systems approach.

DOI: $10.32434 / 2415-3974-2018-8-2-38-43$

\section{Problem statement}

A problem of measuring and estimation of steady development is extraordinarily actual, especially in the conditions of overcoming of consequences of global economic crisis. Steady development envisages the simultaneous decision of versatile and in a great deal contradictory problems of the economy growing on condition of maintenance of quality of environment of residence that is estimated first of all from positions of ecology and social sphere.

Development of theoretic - methodological measuring device of steady development, that will allow simply to interpret the got result presents high both research value and administrative. During many years, after Conference of the UNO on steady development in 1992, many research collectives and leading international organizations develop the different methodological going near the quantitative estimation of firmness. Without regard to that on this moment considerable methodological and practical experience is accumulated in this area, for today there yet is not the generally accepted theoretical and methodological approach an analysis and estimation of steady development of region and such methodology of measuring is in the stage of becoming.

\section{An analysis of the last publications}

In Ukraine the problems of steady development such scientists engage in, as B. Danilishin [12], I. Vahovich [2], Z. Gerasimchuk [3], M. Zgurovc'kii [5], E. Libanova [13], L. Melnik [7], M. Hvectik [8] and others. It is necessary to mark, that considerable work is done in the field of this research. But existent 
regional asymmetries of development of territories of Ukraine require the further improvement of existent knowledge.

The aim of the article is development of research of steady evolution of region on the basis of naturally-resource specialization.

\section{Exposition of basic results}

Under the region can be understood either a separate territorial unit of the administrative division of the country, or education from several territories (regions or regions of different areas), connected with economic, social, cultural, historical and other processes.

From the standpoint of the system approach, the region is a complex socio-economic system, since it consists of a multitude of interconnected elements (subsystems, components) that act as a certain integrity. As a complex system, the region has a number of additional features: the presence of various (material, informational, financial, energy) links between subsystems and subsystem elements; openness of the system; presence in the system of elements of self-organization; participation in the functioning of the system of people, machines and the environment.

Properties of the region as a whole are determined not only and not so much by the properties of its individual elements, but by the properties of its structure, the special integrative properties of this structure. In their various interactions, such elements form the structure of the region.

The region, on the one hand, is a complex socio-economic system, the internal environment of which is an economic, social and ecological subsystem, and on the other hand, a subsystem of a higher hierarchical level. Consequently, the stability of the regional socio-economic system depends both on the stability of the subsystems that are part of it and on the sustainability of higher-level socioeconomic systems, in particular the country as a whole. At the same time, under the stability of the regional socio-economic system, we will understand its ability to function stably and develop in the long run under conditions of a changing internal and external environment, reaching the goal of socioeconomic development of the region, as it seems to us to ensure a positive dynamics of the level and quality of life of the population on the basis of sustainable and balanced reproduction of social, economic, resource and economic potential.

It is fundamentally important to recognize the priority of the social component over sustained economic growth, although it is sustainable growth that serves as a basis for raising the level and quality of life of the population.

The most important methodological task is the definition of factors that ensure the movement of the regional socio-economic system along the trajectory of sustainable development, as well as the justification of criteria and a system of indicators that allow assessing the degree of its sustainability.

Each region has its own specific economic, social, cultural, ethnic, historical, ecological functioning and is a separate element of the regional development management system. The nature of any development has a directed effect on the achievement of a certain goal or system of certain goals. Positive orientation characterizes progress, negative, on the contrary, determines regress or depression. Progressive regional development, in turn, requires an effective system of management of administrative and territorial units and is characterized by positive quantitative and qualitative changes in all spheres of life of the country as a whole and its separate territories.

From the point of view of the set of social and economic goals, regional development can be considered as a multidimensional process that includes various aspects of statehood: growth of production and income; changes in the institutional, social and administrative structures of society; changes in the public consciousness, changes in traditions and habits [4].

Regional development is understood as a mode of functioning of the regional system, which focuses on the positive dynamics of the parameters of the level and quality of life of the population, ensuring sustainable, balanced and complex reproduction of the social, economic, resource and environmental potential of the territory. Modern regional systems are characterized by asymmetry (unevenness, differentiation) of socioeconomic development, that is, the type of regional development, in which there is an increase in regional differences in terms of economic potential, the degree of well-being of the population, as well as other characteristics of the economic and social spheres of regions [4].

The vast majority of methods for assessing the sustainable development of regions at the levels of consideration of both individual countries and certain units within countries is based on the use of comparisons and ranking of regions by rating values.

In the modern world, many projects are being implemented, the purpose of which is to compare and evaluate the various countries of the world. The subject of the study is practically all areas related to human activity. International organizations calculate world indices that characterize economic, political, cultural, and social positions of different countries of the world. The most popular are the following [11]:

- The Failed State Index (FSI) is one of the key international socio-political indicators based on comparing the basic conditions and responsibilities of governments, describing the main social, economic 
and political characteristics of the country. The index is calculated by the Analytical Center for Fund for Peace and the Foreign Policy magazine every year since 2005, analyzing 177 countries that are members of the United Nations. The index is formed from 12 indicators: social - «Demographic pressure», «Mass movement of refugees and internal displacement of the population», "Availability of those who want group revenge» and «Brain outflow»; economic «Uneven economic development of groups» and «Poverty and economic decline»; political «Criminalization / legitimacy of the state», «The deterioration of public services», «Ensuring human rights», «The system works as a» state in the state «», «The ruling elites live for themselves» and «External influences».

- The Global Competitiveness Report (GCR) is the result of a global study of the economic competitiveness of countries around the world. It is calculated according to the methodology of the World Economic Forum since 2004. The World Competitiveness Index consists of 113 variables, which are grouped into 12 indicators that define national competitiveness: «Quality of Institutes», «Infrastructure», «Macroeconomic Stabilit», «Health and Elementary Education», «Higher Education and Training», "Efficiency of the Goods and Services Market», «Labor Market Efficiency», «Financial Market Development», «Technological Development Level», «Internal Market Size», «Quantity of companies» and «Innovative Potential». Each indicator is rated on a scale from 0 to 7 points. A higher score indicates a more positive situation in the country.

- The Globalization Index (KOF Index of Globalization) organizes countries in terms of their global links, integration and independence in the economic, social, technological, cultural, political and environmental spheres; established in 2002 by specialists from the Swiss Economic Institute and the Swiss Federal Institute of Technology. The country's ranking on the globalization index is determined by 24 indicators, which are grouped into three categories:

1) economic globalization (trade, investment, import barriers, average tariffs, international trade taxes, account constraints),

2) social globalization (telephone traffic, international money, international tourism, foreigners, international letters, internet users, television, newspaper trade, McDonald's restaurants, book trade)

3) political globalization (embassies in the province no, membership in international organizations, participation in UN Security Council missions, international agreements).

- The Ease of doing business index (EBI) characterizes the research of the possible implementation of entrepreneurial activity; has been formed since 2002 by the World Bank. The index is represented by 9 indicators: «Opening a business», «Working with construction permits», «Registration of property», «Obtaining a loan», «Investor rights protection», «Tax payment», «International trade», «Enforcement of contracts» and «Closing an enterprise».

- The Index of Economic Freedom (IEF) analyzes the frequency and intensity of government regulation of economic activity, calculated annually by the Wall Street Journal and the Heritage Foundation since 1995, with a ranking of 179 countries. The index is based on 10 indices on a scale from 0 to 100 (index 100 corresponds to maximum freedom): «Freedom of business», «Freedom of trade», «Tax freedom», «Public spending», «Money freedom», «Financial freedom», «Protection of property rights», «Freedom from corruption», «Freedom of labor relations». According to the country's rating, they are divided into «Free», «Overall free», «Relatively free», «Fierce non-free» and «Repressed».

- The most popular among the world community is the Corruption Perceptions Index (CPI), which indicates the degree of corruption in the country; is calculated from Transparency International since 2005 organization Transparency International.

- The Global Peace Index (GPI), which examines the relative position of countries and regions from the point of view of security and peace.

- The Press Freedom Index (PFI), which examines the level of autonomy and editorial independence of media countries [11].

In accordance with the objectives of regional development, a system of criteria (characteristics of development) and indicators that measure their effectiveness are being developed. Despite the existing differences between countries and regions in the hierarchy of values and for development, international organizations assess the degree of development of countries and regions by some universal integrated, aggregating indicators.

Equal as external factors of the region's development, as well as domestic factors, are the use of their own resources and natural opportunities of regions (sources of raw materials, energy, natural materials, etc.), human resources (labor), own financial resources, experience and knowledge domestic researchers, the achievement of domestic science and technology, etc.

For the estimation of degree of steady development of region drawn on the set of separate indexes in their dynamics. Most known the methods of diagnostics of degree of steady development following:

- after the scope of variation (a difference is 
between a maximal and minimum value);

- after the level of variation, \%;

- after the level of differentiation (attitude of

maximal value is toward minimum);

- after the modified coefficient of variation of

B. Lavrovc'kogo;

- after the self-weighted coefficient of variation

of Williamson;

- after a coefficient Gini;

- after the function of public prosperity of A. Atkinson;

- after Theil index;

- after the coefficient of Herfindahl;

- a quintile coefficient;

- an expedient coefficient;

- after the level of importance of asymmetry.

Soviet scientists of HAH of Ukraine express opinion, that regions have certain naturally-resource specialization that considerably influences on potential of development of regions. They mark that, the achievement of steady development of regions of naturally-resource specialization objectively envisages the effective use them natural (geographical) competitive edges, as a regional economy is in a greater degree related to the naturally-geographical factors - presence of minerals, other types of natural resources, energy, favourable terms of geographical environment sources [13]. It specifies on dependence of level of economic development of region on the presence of natural factors and state of environment.

As known, natural resources are components of nature, natural and climatic terms are forces of nature, that influence on the vital functions of population and economic activity, that is needed for the receipt of eventual foods. A human capital (potential) of region is a category, that represents, firstly, possibilities and expediency of conduct of entrepreneurial activity in a that or other region, secondly, efficiency of the use of human capital in the separately taken region of country, due to a grant to possibility to get a fee for his use with the aim of satisfaction of own necessities, and also investing in his further development.

As the most important component of the national wealth of the country, the socio-economic potential of each region of Ukraine, human capital directly influences reproduction processes, it depends on it on profit making in the economy, the filling of budgets of different levels, qualitative changes in the structure of the economy, the increase of production efficiency and the attractiveness of the social sphere. , achievements in scientific, technical, technological, innovative projects, level of quality of life of the population [15].

For measuring of level of steady development of region, the Ukrainian scientists use an index «Index of steady development of region» $[2,3,5,7$,
8, 13 and other]. Most researchers in basis of this index inlay the indexes of economic, social and ecological constituent, незважаючи attention on naturally-resource specialization of region and state of him natural pесрсів. In our view, it is important, also to have imagination about naturally - resource constituent of region, because existent regional asymmetries of development at Ukraine specify on the underestimation of potential of development of regions, or quite absence of knowledge about potential possibilities of territory. From higher described, the system of steady development of region is generalized we suggest to present as intercommunication four constituents - economic, social, naturally - resource and ecological. The system of estimation of steady development of region it maybe to present as follows (Figure).

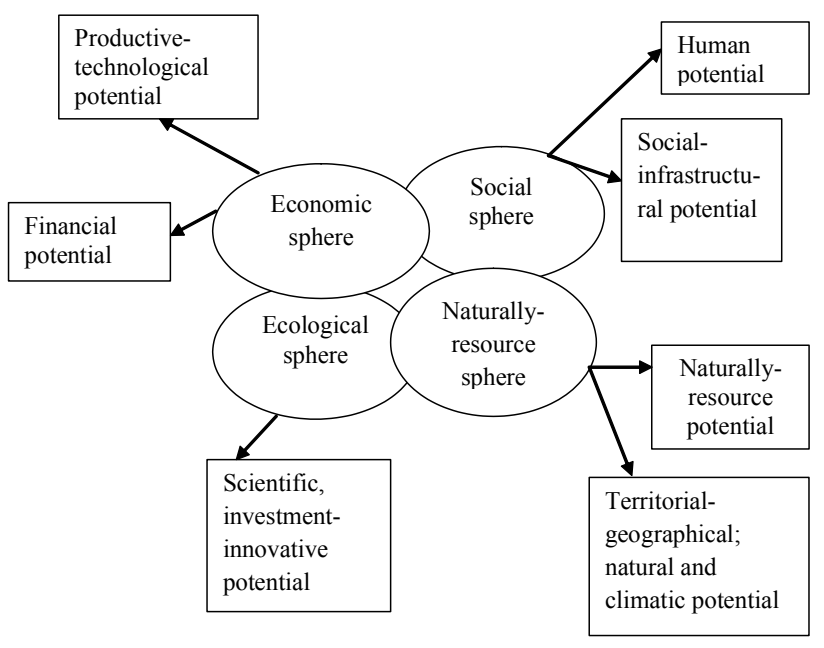

Structure of system of assessment of sustainable development of a region, author's elaboration

From Figure evidently, that naturally - folds a resource constituent naturally is resource potential and territorial - geographical and naturally is climatic potential. By indexes naturally - resource potential, that it maybe to use for settling of estimation of steady development of region can be:

- a volume of beds of minerals;

- distribution of the landed area and agricultural lands;

- indexes of conduct of the hunting growing;

- indexes of conduct of forestry;

- an index of getting of water bioresources;

- basic indexes of water-supply and overflowpipe.

By indexes territorial - geographical and naturally - climatic potential there can be such:

- an amount of the rivers and pestilences;

- an amount of mountain peaks;

- an amount of precipitations that fell out;

- belonging to the area of risky agriculture; 
- an amount of religious organizations;

- intensity of transportations of loads after the types of ways of report of the general use.

Thus, in our view expansion of circle of indexes for the estimation of steady development of region, namely indexes naturally - resource constituent will give possibility to measure potential possibilities of region on the basis of naturally - resource specialization.

Conclusions

The presence of a significant number of world indexes, which characterize the indicators of development and positions of different countries, confirms the urgency and significance of the attention of the world community to assess the level of sustainable development of the region.

As a result of research of the existent methodological going near the estimation of level of steady development of region absence of important constituent was educed. In our view a complex estimation of steady development of region must be taking into account naturally - resource specialization of region. Removal of the marked problems of methodology of research of steady development, to our opinion, possible due to taking into account of indexes naturally - resource potential and indexes territorial - geographical and naturally - climatic potential to the estimation of integral index of steady development of region. Such settling, in further, will give possibility to define priorities of stimulation of development of problem territories to us. It will give possibility to inculcate effective measures in relation to opening of potential of regions on the basis of their naturally to us - resource specialization and from position of approach of the systems.

\section{REFERENCES}

1. Babets' I.G. (2012). Teoretiko-metodichni pidkhodi do otsinki ekonomichnoï bezpeki interregional'nogo spivrobitnitstva [Theoretical and methodological approaches to the assessment of economic security without interregional spivrobitnittva]. Naukoviy visnik Chernivets'kogo natsional'nogo universitetu: Zb. nauk. prats'. Ekonomika, pp.299-305 [in Ukrainian].

2. Vakhovich I.M., Tabalova O.E. (2012). Regional'ni asimetriï stalogo rozvitku Ukraïni: diagnostika ta mekhanizmi virivnyuvannya [Regional Asymmetries of Sustainable Development in Ukraine: Diagnostics and Equalization Mechanisms]. Luts'k: «Volin'poligraf». 344p. [in Ukrainian].

3. Gerasimchuk Z.V., Polishchuk V.G. (2010). Kontseptual'ni zasadi stimulyuvannya stalogo rozvitku regionu [Conceptual bases of stimulation of sustainable development of the region]. Ekonomika i region, Vol. 1 (24), pp.8-15 [in Ukrainian].

4. Grebenkin A. S., Skripnyu D. F. (2005). Asimmetriya razvitiya regionov: faktory vozniknoveniya i regulirovanie
[Elektronnyy resurs] [Asymmetry of regional development: factors of occurrence and regulation]. Nalogi. Investitsii. Kapital, Vol. 1. Access mode: http://nic.pirit.info/20050 [in Ukrainian].

5. Zgurovskiy M. Z., Pankratova N .D. (2005). Sistemnyy analiz: problemy, metodologiya, prilozheniya [System Analysis: Problems, Methodology, Applications]. K.: Naukova dumka, 744p. [in Ukrainian].

6. Ekonomika regioniv u 2015 rotsi: novi realii i mozhlivosti $\mathrm{v}$ umovakh zapochatkovanikh reform [The region's economy in 2015: new realities and opportunities in the context of the initiated reforms]. K.: NISD, 92 p. [in Ukrainian].

7. Mel'nik L.G. (2007). Ponyattya pro staliy rozvitok [Concept of Sustainable Development]. Sumi: VTD «Universitets'ka kniga», pp.411-442 [in Ukrainian].

8. Khvesik M.A. (2013). Naukovi osnovi natsional'noï strategii stalogo rozvitku Ukraïni [Scientific fundamentals of the national strategy of sustainable development of Ukraine]. K.: DU IEPSR NAN Ukraïni, 40 p. [in Ukrainian].

9. Paton B. E. (2012). Natsional'na paradigma stalogo rozvitku Ukraïni [National Paradigm of Sustainable Development of Ukraine]. K.: Derzhavna ustanova «Institut ekonomiki prirodokoristuvannya ta stalogo rozvitku Natsional'noï akademiï nauk Ukraïni», 72 p. [in Ukrainian].

10. Mel'nik L.G. (2005). Osnovi stiykogo rozvitku [Basics of Sustainable Development]. Sumi: VTD «Universitets'ka kniga», 654 p. [in Ukrainian].

11. Prokopishin T. (2012). Ukraïna-2012 u svitovikh reytingakh [Elektronniy resurs] [Ukraine-2012 in world rankings]. Access mode: http://blogs.tvi.ua/2013/01/04/ ukrayina_2012_u_svitovykh_indeksakh [in Ukrainian].

12. Danilishina B.M. (1998). Rozrobka integrovanikh pokaznikiv stanu navkolishn'ogo seredovishcha ta mekhanizmiv ïkh navkolishn'ogo seredovishcha v Natsional'ni Plani Diy shchodo okhoroni prirodi [Development of integrated indicators of the state of the environment and their environmental mechanisms in the National Action Plans for the Conservation of Nature]. Kiïv: «VIPOL», 60 p. [in Ukrainian].

13. Libanova E.M., Khvesik M.A. (2014). Sotsial'noekonomichniy potentsial stalogo rozvitku Ukraïni ta iï regioniv: natsional'na dopovid' [Socio-economic potential of sustainable development of Ukraine and its regions: national report]. K.: DU IEPSR NAN Ukraïni, 776 p. [in Ukrainian].

14. A. Sadovenko, L. Maslovs'ka, V. Sereda, T. Timochko. (2011). Staliy rozvitok suspil'stva [Sustainable development of society]. K.: Naukova dumka, 392 p. [in Ukrainian].

15. Fedulova S.O. (2013). Lyuds'kiy kapital regionu: retrospektiva ta suchasna ekonomichna nauka [Human capital of the region: retrospective and modern economic science]. Naukovi zapiski. Seriya «Ekonomika», Vol. 23, pp. 121 - 124 [in Ukrainian].

Received 21.10.18 Reviewer: Doct of Econ.Sc., prof. Garmider L.D. 


\section{ОЦІНЮВАННЯ СТАЛОГО РОЗВИТКУ РЕГІОНУ НА ОСНОВІ ПРИРОДНО-РЕСУРСНОЇ СПЕЦІАЛІЗАЦІЇ}

\section{Федулова С.О., Білоброва О.В.}

У статті проаналізовано існуючі підходи до оцінювання рівня сталого розвитку регіону. Зазначено, що дана проблема має широке висвітлення, але існуючі регіональні асиметрії розвитку територій України вимагають подальшого удосконалення існуючого знання. 3 позиції системного підходу регіон є складною соціально-економічною системою, так як складається 3 безлічі взаємозалежних елементів (підсистем, компонентів), які виступають, як певна цілісність. Важливим методологічним завданням виступає визначення чинників, що забезпечують рух регіональної соціально-економічної системи по траєкторії сталого розвитку, а також обгрунтування критеріїв $i$ системи показників, які дозволяють оцінити ступінь їі стійкості. Переважна кількість методик оцінки сталого розвитку регіонів на рівнях розгляду як окремих країн, так $і$ певних одиниць всередині країн базується на використанні порівняння та упорядкуванні регіонів за значеннями рейтингів. Предметом дослідження виступають практично всі напрямки, пов 'язані з життєдіяльністю людини. Відповідно до иілей регіонального розвитку будується система критеріїв (характеристик розвитку) і показників, які вимірюють їх ефективність. Незважаючи на існуючі відмінності між країнами і регіонами в ієрархї цінностей $і$ в цілях розвитку, міжннародні організації оцінюють ступінь розвитку країн і регіонів за деякими універсальними інтегральними, узагальнюючими показниками.Розробка теоретико-методологічного апарата виміру сталого розвитку, який дозволить однозначно трактувати отриманий результат являє високу як дослідницьку иінність, так і управлінську. У статті запропоновано врахування природно - ресурсної спеціалізації регіону при розробці теоретичних основ оцінки сталого розвитку регіону.

Ключові слова: регіон; сталий розвиток; індекс; рейтинг; природно - ресурсна спеціалізація регіону; територіальний розвиток; системний підхід.

\section{ОЦЕНКА УСТОЙЧИВОГО РАЗВИТИЯ РЕГИОНА НА ОСНОВЕ ПРИРОДНО-РЕСУРСНОЙ СПЕЦИАЛИЗАЦИИ}

\section{Федулова С.А., Белоброва Е.В.}

В статье проанализированы существующие подходы к оценке уровня устойчивого развития региона. Отмечено, что данная проблема имеет широкое освещение, но существующие региональные асимметрии развития территорий Украины требуют дальнейшего совершенствования существующего знания. С позиции системного подхода регион является сложной социально-экономической системой, так как состоит из множества взаимосвязанных элементов (подсистем, компонентов), которые выступают как определенная целостность. Важным методологическим заданием выступает определение факторов, обеспечивающих движение региональной социально-экономической системы по траектории устойчивого развития, а также обоснование критериев и системы показателей, позволяющих оценить степень ее устойчивости. Подавляющее количество методик оценки устойчивого развития регионов на уровнях рассмотрения как отдельных стран, так и определенных единиц внутри стран базируется на использовании сравнения и упорядочения регионов по значениям рейтингов. Предметом исследования выступают практически все направления, связанные с жизнедеятельностью человека. В соответствии с целями регионального развития строится система критериев (характеристик развития) и показателей, которые измеряют их эффективность. Несмотря на существуюшие различия между странами и регионами в иерархии ценностей и в целях развития, международные организации оценивают степень развития стран и регионов по некоторым универсальным интегральным, обобщающим показниками. Розробка теоретико методологического аппарата измерения устойчивого развития, который позволит однозначно трактовать полученный результат представляет высокую исследовательскую и управленческую иенность. В статье предложено учитывать природно - ресурсную специализацию региона при разработке теоретических основ оценки устойчивого развития региона.

Ключевые слова: регион; устойчивое развитие; індекс; рейтинг; природно - ресурсная специализация региона; территориальное развитие; системный подход. 